\title{
Angiostrongylus minasensis n. sp.: new species found parasitizing coatis (Nasua nasua) in an urban protected area in Brazil
}

\author{
Angiostrongylus minasensis $n$. sp.: nova espécie encontrada parasitando \\ quatis (Nasua nasua) em área de proteção urbana no Brasil
}

Lara Ribeiro de Almeida1, Joyce Gonçalves Rosário de Souza², Hudson Andrade Santos, Eduardo José Lopes Torres ${ }^{3}$, Roberto do Val Vilela², Olívia Monique Soares Cruz, Leonardo Rodrigues ${ }^{4}$, Cíntia Aparecida de Jesus Pereira ${ }^{1}$, Arnaldo Maldonado Junior ${ }^{2}$, Walter dos Santos Lima1* (1)

\footnotetext{
${ }^{1}$ Laboratório de Helmintologia Veterinária, Departamento de Parasitologia, Instituto de Ciências Biológicas, Universidade Federal de Minas Gerais - UFMG, Belo Horizonte, MG, Brasil

${ }^{2}$ Laboratório de Biologia e Parasitologia de Mamíferos Silvestres Reservatórios, Fundação Oswaldo Cruz - FIOCRUZ, Rio de Janeiro, RJ, Brasil

${ }^{3}$ Laboratório de Helmintologia Romero Lascasas Porto, Departamento de Microbiologia, Imunologia e Parasitologia, Faculdade de Ciências Médicas, Centro Biomédico, Universidade do Estado do Rio de Janeiro - UERJ, Rio de Janeiro, RJ, Brasil ${ }^{4}$ Escola Estadual de Ensino Fundamental e Médio Graça Aranha, Secretaria da Educação - SEDU, Santa Maria de Jetibá, ES, Brasil
}

How to cite: Almeida LR, Souza JGR, Santos HA, Torres EJL, Vilela RV, Cruz OMS, Rodrigues L, Pereira CAJ, Maldonado Junior A, Lima WS. Angiostrongylus minasensis n. sp.: new species found parasitizing coatis (Nasua nasua) in an urban protected area in Brazil. Braz J Vet Parasitol 2020; 29(1): e018119. https://doi.org/10.1590/S1984-29612019103

\begin{abstract}
Currently, there are 21 species of Angiostrongylus that parasitize the pulmonary or mesenteric arteries of wild and domestic rodents, felids, canids and human. Species of Angiostrongylus have cosmopolitan distribution covering tropical, subtropical and temperate regions. The procyonid Nasua nasua (coati) is a reservoir host for a wide variety of parasites that may be harmful to its populations or may contain etiological agents with zoonotic potential. In urban areas, coatis are usually found in close association with humans and domestic animals. We morphologically and molecularly characterized a new species of Angiostrongylus found in N. nasua in a protected area within Belo Horizonte, Brazil. The new species of Angiostrongylus differs from other species of the same genus in terms of the length and bifurcation level of the lateral and ventral rays, the length of spicules and female tail morphology. Molecular phylogenetic results based on the mitochondrial cytochrome c oxidase subunit 1 gene suggest that the newly identified species belongs to a genetic lineage that is separate from other species of Angiostrongy/us. This new species was collected from the mesenteric arteries of $N$. nasua. It was named Angiostrongylus minasensis n. sp..
\end{abstract}

Keywords: Angiostrongylus minasensis, taxonomy, morphology, morphometric and phylogenetic analysis, Nasua nasua.

\section{Resumo}

Existem 21 espécies de Angiostrongylus que parasitam as artérias pulmonares ou mesentéricas de roedores silvestres e domésticos, felídeos, canídeos e homem. Espécies de Angiostrongylus têm uma distribuição cosmopolita que abrange regiões tropicais, subtropicais e temperadas. O procionídeo Nasua nasua (quati) é hospedeiro de vários parasitos que podem ser prejudiciais para suas populações ou conter agentes etiológicos com potencial zoonótico. Nas áreas urbanas, os quatis 
podem ser encontrados em estreita associação com seres humanos e animais domésticos. Nós caracterizamos morfológica e molecularmente uma nova espécie de Angiostrongylus encontrada em N. nasua de uma área protegida na cidade de Belo Horizonte, Brasil. A nova espécie de Angiostrongylus difere de outras espécies do mesmo gênero pelo comprimento e nível de bifurcação dos raios lateral e ventral, o comprimento dos espículos e a morfologia da cauda da fêmea. Resultados moleculares e filogenéticos baseados no gene mitocondrial citocromo c oxidase subunidade 1 indicam que a espécie recém-identificada pertence a uma linhagem genética separada de outras espécies de Angiostrongylus. O presente relato descreve uma nova espécie de Angistrongylus coletada das artérias mesentéricas de N. nasua, denominada Angiostrongylus minasensis n. sp..

Palavras-chave: Angiostrongylus minasensis, taxonomia, morfologia, análise morfométrica e filogenética, Nasua nasua.

\section{Introduction}

Species of the genus Angiostrongylus Kamensky, 1905, have widespread geographical distribution and have been reported in Australia, Americas, Asia, Africa and Europe (Jefferies et al., 2009). Currently, 21 species of Angiostrongylus are known the world (Maldonado et al., 2012). Species have been described parasitizing carnivores: Angiostrongylus vasorum (Baillet, 1866); A. gubernaculatus (Dougherty, 1946); A. chabaudi (Biocca, 1957); A. daskalovi (Yanchev \& Genov, 1988); and A. felineus (Vieira et al., 2013). Other species have been described in rodents or occasionally in aberrant hosts (Spratt, 2015): A. taterone (Baylis, 1928); A. cantonensis (Chen, 1935); A. sciuri (Merdevenci, 1964); A. mackerrasae (Bhaibulaya, 1968); A. sandarsae (Alicata, 1968); A. petrowi (TARJYMANOVA \& TSCHERTKOVA, 1969); A. dujardini (Drozdz \& Doby, 1970); A. schmidti (Kinsella, 1971); A. costaricensis (Morera \& Cespedes, 1970); A. malaysiensis (Bhaibulaya \& Cross, 1971); Angiocaulus ryjikovi (Jushkov, 1971); A. andersoni (PETTER, 1972); A. siamensis (Ohbayashi et al., 1979); A. morerai (Robles et al., 2008); and A. lenzii (Souza et al., 2009).

The coati, Nasua nasua (Procyonidae) Linnaeus, 1766, is common in South America (Decker, 1991). Coatis live preferentially in forested environments, are diurnal and omnivorous. In urban environments, and thus in recreational areas, coatis may reach high population densities and are found in close association with humans and domestic animals (Crespo, 1982; Gompper \& Decker, 1998; Alves-Costa et al., 2004).

We describe a new species of Angiostrongylus that was found parasitizing the mesenteric arteries of specimens of $N$. nasua that had been collected in a protected area in the state of Minas Gerais, Brazil. We characterized the new species by means of optical and scanning electron microscopy (SEM) and used molecular phylogenetic analysis to determine its relationships within the family Angiostrongylidae. The species was named Angiostrongylus minasensis $\mathrm{n}$. $\mathrm{sp}$..

\section{Materials and Methods}

\section{Origin of the parasites}

Ten road-killed specimens of Nasua nasua (four adult females, four adult males and two young females) were collected in the Mangabeiras Municipal Park, an environmental conservation area located in Belo Horizonte, the capital of the state of Minas Gerais,

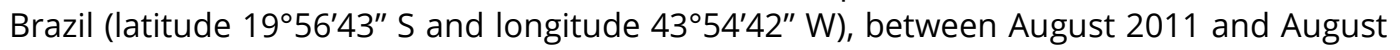
2016. The carcasses were sent to the Helminthology Laboratory of the Institute of Biological Sciences, Federal University of Minas Gerais (UFMG). The study was authorized through the system for authorizations and for biodiversity information (SISBIO) of the Chico Mendes Institute for Conservation and Biodiversity [ICMBio/39817-1, ICMBio/54546-1] and by UFMG's ethics committee for use of animals [306/2017]. 
Nematodes were collected from the mesenteric arteries of the coati specimens. They were washed in $0.85 \%$ saline solution and fixed in $10 \%$ formalin at $80{ }^{\circ} \mathrm{C}$ for morphological and morphometric analyses, as described by Lima et al. (1985), or were placed in $100 \%$ ethanol and stored at $-20^{\circ} \mathrm{C}$ for molecular analysis. Feces were recovered from the rectum of all the necropsied animals, and then first stage (L1) larvae were isolated using the Baermann apparatus (Barçante et al., 2003).

\section{Microscopy analysis}

The paratypes (10 males and 10 females), included one holotype (male), and one allotype (female) were cleared in Amann's lactophenol. Measurements were made in millimeters (unless otherwise stated). These measurements are presented as holotype or allotype values, followed by the interval, mean and variation coefficient between parentheses.

Images were captured using a digital camera attached to an optical microscope. Drawings were made with the aid of a camera lucida. The new Angiostrongylus species was morphologically identified using the method of Anderson et al. (2009). Nematodes were prepared for conventional SEM as previously described (Lopes et al., 2013) and observed using the Zeiss Auriga Compact equipment at the urogenital research unit of the State University of Rio de Janeiro.

\section{DNA isolation, PCR and sequencing}

Genomic DNA was isolated from adult nematode specimens that were recovered from the mesenteric arteries of the coatis using the QIAGEN ${ }^{\circ}$ QIAamp ${ }^{\circledR}$ DNA mini kit, following the manufacturer's protocol. The polymerase chain reaction (PCR) was carried out using a primer cocktail, as described by Prosser et al. (2013), to produce amplicons of the cytochrome c oxidase subunit 1 gene (MT-CO1), using the Invitrogen ${ }^{\mathrm{TM}}$ Platinum $^{\mathrm{TM}}$ Taq DNA polymerase.

After checking the PCR products on agarose gel check, they were then purified using the GE Healthcare Illustra ${ }^{\mathrm{TM}}$ GFX ${ }^{\mathrm{TM}}$ PCR DNA and Gel Band purification kit, following the manufacturer's protocol. Purified amplicons were cycle-sequenced using the Applied Biosystems $^{\mathrm{TM}}$ BigDye $^{\mathrm{TM}}$ Terminator $\mathrm{v} 3.1$ cycle sequencing kit individually using each of the six primers from the above-mentioned cocktail (Prosser et al., 2013). Sequencing was performed using the $A B I 3730$ DNA analyzer at the DNA sequencing platform of the Oswaldo Cruz Institute (PDTIS/FIOCRUZ). Six overlapping fragments for each sample were assembled into contigs, and ambiguities were edited to generate a consensus sequence for each specimen, using the Geneious 9.1 software package with default parameters (http://www.geneious.com) (Kearse et al., 2012).

\section{Phylogenetic analyses}

Consensus sequences were aligned with GenBank sequences of representative members of the family Angiostrongylidae, four species of the metastrongyloid taxa (Protostrongylus rufescens, Metastrongylus pudendotectus, M. salmi and Parafilaroides normani) and two unpublished sequences of Heterostrongylus heterostrongylus. Two strongylid GenBank sequences were used as outgroups: Ancylostoma duodenale and Necator americanus (Table 1). 
Table 1. Accession numbers of nematode MT-CO1 gene sequences retrieved from GenBank and respective hosts, sites of infection, geographical origin, and references.

\begin{tabular}{|c|c|c|c|c|c|}
\hline Referred species & $\begin{array}{c}\text { GenBank } \\
\text { accession }\end{array}$ & Host & $\begin{array}{c}\text { Site of } \\
\text { infection }\end{array}$ & $\begin{array}{l}\text { Geographical } \\
\text { origin }\end{array}$ & Reference \\
\hline Necator americanus & AJ417719 & Human & $\begin{array}{c}\text { Small } \\
\text { intestine }\end{array}$ & China & Hu et al. (2002) \\
\hline Ancylostoma duodenale & AJ417718 & Human & $\begin{array}{c}\text { Small } \\
\text { intestine }\end{array}$ & China & Hu et al. (2002) \\
\hline Aelurostrongylus abstrusus & JX519458 & Felis catus & Lung & - & Jabbar et al. (2013a) \\
\hline Heterostrongylus heterostrongylus & $X X X X X$ & $\begin{array}{l}\text { Didelphis } \\
\text { aurita }\end{array}$ & Lung & Brazil & Costa et al. (2016) \\
\hline H. heterostrongylus & $X X X X X$ & $\begin{array}{l}\text { Didelphis } \\
\text { aurita }\end{array}$ & Lung & Brazil & Costa et al. (2016) \\
\hline Metastrongylus pudendotectus & NC_013813 & Pig & $\begin{array}{l}\text { Terminal } \\
\text { bronchi in } \\
\text { the lungs }\end{array}$ & Estonia & Jex et al. (2010) \\
\hline Metastrongylus salmi & NC_013815 & Pig & $\begin{array}{l}\text { Terminal } \\
\text { bronchi in } \\
\text { the lungs }\end{array}$ & Estonia & Jex et al. (2010) \\
\hline Parafilaroides normani & NC_024656 & $\begin{array}{c}\text { Arctocephalus } \\
\text { pusillus }\end{array}$ & Lung & Australia & Jabbar et al. (2014) \\
\hline Protostrongylus rufescens & NC_023262 & Sheep & Lung & Australia & Jabbar et al. (2013b) \\
\hline Angiostrongylus vasorum & GQ982735 & $\begin{array}{c}\text { Canis } \\
\text { familiaris }\end{array}$ & $\begin{array}{c}\text { Heart and } \\
\text { pulmonary } \\
\text { arteries }\end{array}$ & United Kingdom & Jefferies et al. (2010) \\
\hline A. vasorum & GQ982871 & Vulpes vulpes & $\begin{array}{l}\text { Heart and } \\
\text { pulmonary } \\
\text { arteries }\end{array}$ & Portugal & Jefferies et al. (2010) \\
\hline A. chabaudi & KU521521 & Felis silvestris & $\begin{array}{c}\text { Heart and } \\
\text { pulmonary } \\
\text { arteries }\end{array}$ & Romania & Gherman et al. (2016) \\
\hline A. cantonensis & GQ398121 & $\begin{array}{c}\text { Rattus } \\
\text { norvegicus }\end{array}$ & $\begin{array}{c}\text { Pulmonary } \\
\text { arteries }\end{array}$ & China & Lv et al. (2012) \\
\hline A. malaysiensis & KT947979 & Rattus rattus & $\begin{array}{l}\text { Heart and } \\
\text { lung }\end{array}$ & Malaysia & Yong et al. (2016) \\
\hline A. costaricensis & KX378965 & Nasua narica & $\begin{array}{c}\text { Mesenteric } \\
\text { vessels }\end{array}$ & Costa Rica & Santoro et al. (2016) \\
\hline A. costaricensis & KR827449 & - & $\begin{array}{l}\text { Mesenteric } \\
\text { vessels }\end{array}$ & Costa Rica & Yong et al., (2015) \\
\hline A. costaricensis & GQ398122 & - & $\begin{array}{l}\text { Mesenteric } \\
\text { vessels }\end{array}$ & Brazil & Lv et al. (2012) \\
\hline A. minasensis n. sp. & $X X X X X$ & Nasua nasua & $\begin{array}{l}\text { Mesenteric } \\
\text { vessels }\end{array}$ & Brazil & Present study \\
\hline
\end{tabular}

(-) data absent in the original article; XXXXX: not published.

The alignment was done as described by Maddison \& Maddison (2015). The incidence of substitution saturation was verified using the test suggested by Xia et al. (2003) and Xia (2009). In addition, plots of Jukes \& Cantor (1969) pairwise distances against transitions and transversions were used for each codon position. We carried out both tests using the DAMBE software, version 5.6.14 (Xia, 2013).

Phylogenetic reconstructions were carried out using maximum likelihood (ML) and Bayesian inference (BI) as optimality criteria using the software Treefinder version of March 2011 (Jobb, 2011) and MrBayes version 3.2.6 (Ronquist et al., 2012), respectively. 
To account for different evolutionary processes at each of the three codon positions, $\mathrm{ML}$ and $\mathrm{BI}$ analyses were performed with distinct models per codon position.

ML-pairwise distances were computed using the same codon-based partitioned models (Schwarz, 1978). The robustness of nodes in ML was assessed by means of nonparametric bootstrap percentages (BP) after 1,000 pseudo-replicates had been produced, and by means of the expected-likelihood weights, which were applied to local rearrangements of tree topology (LR-ELW) after 1,000 replicates.

In the $\mathrm{BI}$ analyses, distinct GTR $+1+\Gamma$ models were used for each codon position, with unlinking of base frequencies and parameters. Markov chain Monte Carlo (MCMC) sampling was performed for 10,000,000 generations with four simultaneous chains, in two runs. The robustness of nodes in BI was assessed by means of Bayesian posterior probabilities (BPP), which were calculated from trees that were sampled every 100 generations. The adequacy of $\mathrm{BI}$ analysis sampling was assessed using the Tracer software, version 1.6 (Rambaut et al., 2014). Presence of more than 100 effectively independent samples was considered sufficient. To save computational time, $\mathrm{BI}$ analyses were carried out on XSEDE cluster using the CIPRES Science Gateway (Miller et al., 2010).

\section{Results}

Angiostrongylus minasensis n. sp. (Figures. 1-4)

Type host. Nasua nasua (Linnaeus, 1766) (Carnivora: Procyonidae); common name: coati.

Type locality. Mangabeiras Park, Belo Horizonte, state of Minas Gerais, Brazil ( $9^{\circ} 56^{\prime} 43^{\prime \prime}$ S $43^{\circ} 54^{\prime} 42^{\prime \prime}$ W).

Site in host. Mesenteric arteries (Figure 1).
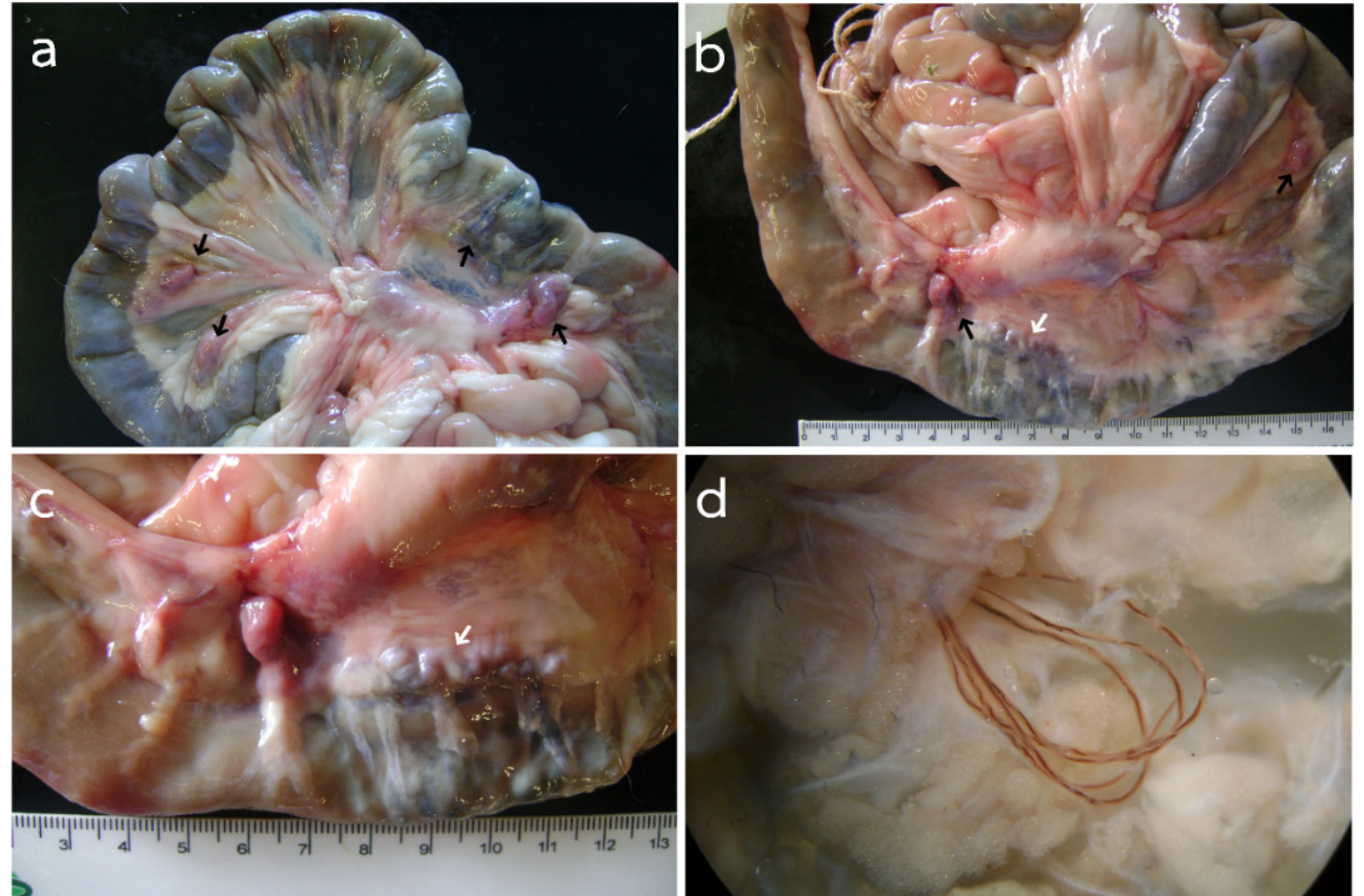

Figure 1. Angiostrongylus minasensis on the mesenteric arteries. The black arrows indicate nodules on the mesentery $(a, b)$. The white arrows point to blood vessels $(b, c)$. The parasite recovered from blood vessels $(d)$. 
Prevalence. $100 \%(n=10)$.

Type material. Holotype male (CHIOC number 38505a) and allotype female (CHIOC number 38505b). Deposited in the Oswaldo Cruz helminthological collection (CHIOC), Rio de Janeiro, Brazil.

Etymology. The species name refers to the place where the new species was isolated.

\section{Description}

General. (Figures 2a and 3a) Body of both sexes filiform with transparent transversally striated cuticle. Oral aperture simple. Esophagus short and claviform. Excretory pore posterior to esophago-intestinal junction. Nerve ring anterior to the middle of esophagus. SEM results showed details of the cuticular topography, including important taxonomical structures. Anterior end of male and female is characterized by the presence of a circular oral opening surrounded by six sensory papillae and two amphids. The papillae are distributed in two dorsal and four lateroventral and amphids on the lateral position of the anterior end (Figure $4 a$ and b). Dorsal side of the mouth presents a structure with a cleft, which was named a tooth-like structure (Figure 4b).
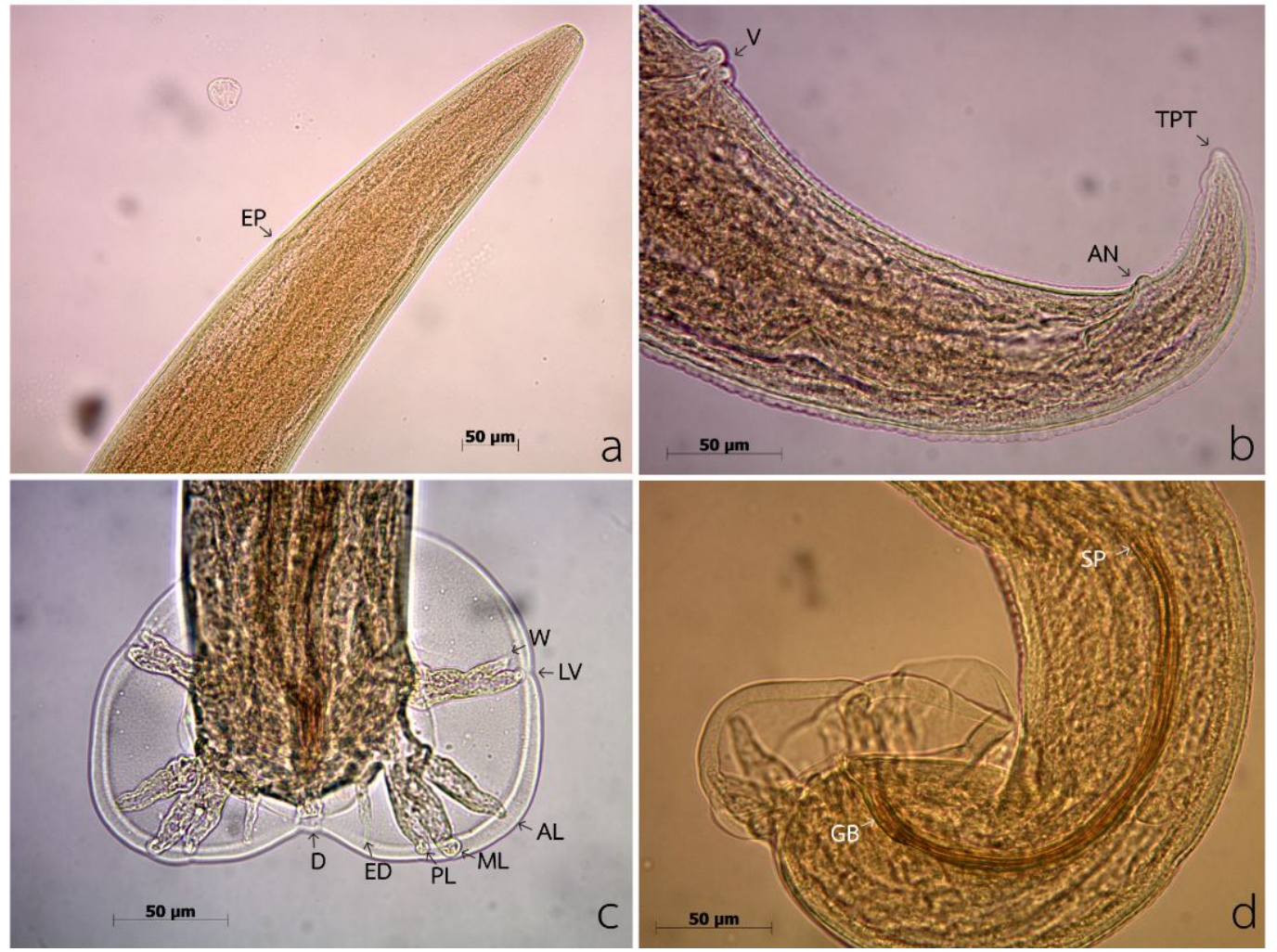

Figure 2. Adult specimen of Angiostrongylus minasensis. Anterior extremity showing the excretory pore (a). Female posterior extremity showing the vulva (V), anus (AN) and the tip of the tail (TPT) (b). Ventral view of the copulatory bursa, with the ventro-ventral (VV) and lateroventral (LV) rays emerging from the same trunk; lateral rays divided into anterolateral (AL), mediolateral $(\mathrm{ML})$ and posterolateral (PL); and externodorsal (ED) and dorsal (D) rays (c). Lateral view of the copulatory bursa showing the gubernaculum (GB) and the size of the spicule (SP) (d). 


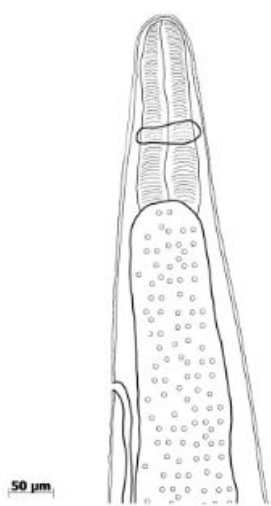

a

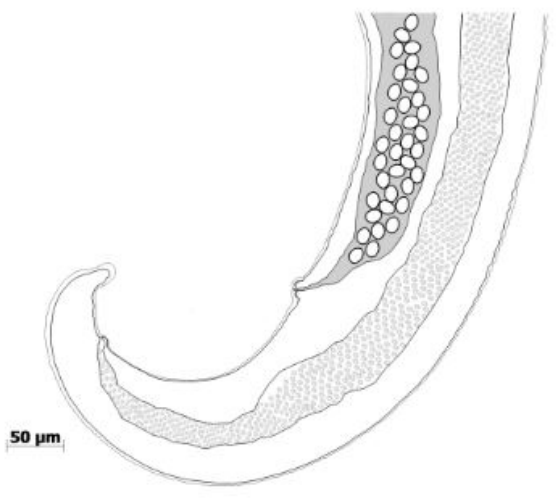

b

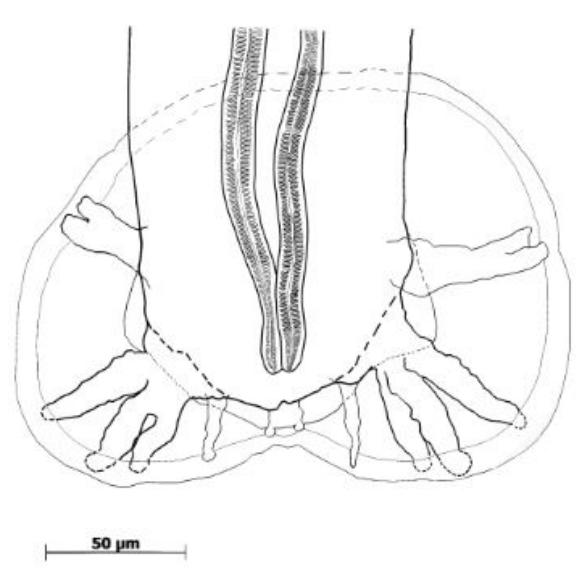

C
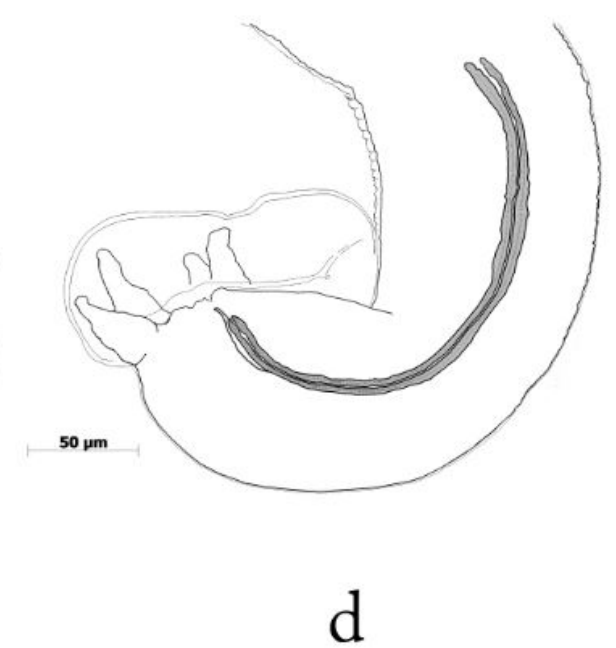

Figure 3. Drawings of $A$. minasensis using optical microscopy in association with a camera lucida. Female anterior extremity (a). Female posterior extremity (b). Ventral view of posterior extremity of male, showing the copulatory bursa (c). Posterior extremity of male in lateral view, showing the spicules and gubernaculum (d).

Male. [Based on one holotype and 10 paratypes; Figure 2c, 2d, 3c and 3d] Body $13.22 \mathrm{~mm}$ [12.12-14.1 (13.27 \pm 0.67$)]$ long and $0.17 \mathrm{~mm}[0.19-0.22(0.2 \pm 0.01)]$ wide. Esophagus $0.25 \mathrm{~mm}[0.20-0.25(0.23 \pm 0.02)]$ long and $0.04 \mathrm{~mm}[0.03-0.04(0.03 \pm 0.005)]$ wide at its base. Nerve ring and excretory pore $0.073 \mathrm{~mm}[0.064-0.075(0.07 \pm 0.005)]$ and $0.37 \mathrm{~mm}$ [0.3-0.37 $(0.34 \pm 0.03)]$ from anterior end, respectively. Caudal extremity ventrally curved. Copulatory bursa symmetrical and small. Ventral rays have a common origin, bifurcating distally; lateroventral ray is longer and more robust than ventro-ventral ray. Lateral rays emerge from a common trunk and are similar in size; antero-lateral ray is robust and separate from the common trunk close to the base; mediolateral and posterolateral rays are separated close to the extremity. Externo dorsal rays are separate from the dorsal ray and are longer and more slender. The dorsal ray is reduced and bifurcates distally into two small branches. Spicules short, equal in size with a striated sheath, $0.25 \mathrm{~mm}$ [0.24-0.27 (0.25 \pm 0.012$)]$ length. Gubernaculum $0.039 \mathrm{~mm}$ [0.034-0.045 $(0.04 \pm 0.003)]$ in length. SEM results showed symmetrical copulatory bursa with quadrangular aspect and two spicules (Figure 4d). On the dorsal face, it was possible to 
identify the external lateral and dorsal rays (Figure 4d). Ventral, lateral and dorsal trunks were observed and, in addition, it was possible to differentiate the lateral trunk divided into three rays: anterolateral, mediolateral and posterolateral (Figure $4 \mathrm{~d}$ and e). At the end of the anterolateral ray on both sides, near to the bursal edge, we identified one papilla (Figure $4 \mathrm{~d}$ and $\mathrm{f}$ ). The spicules were everted, trough-shaped, and the surface presented a striated external appearance (Figure 4f).
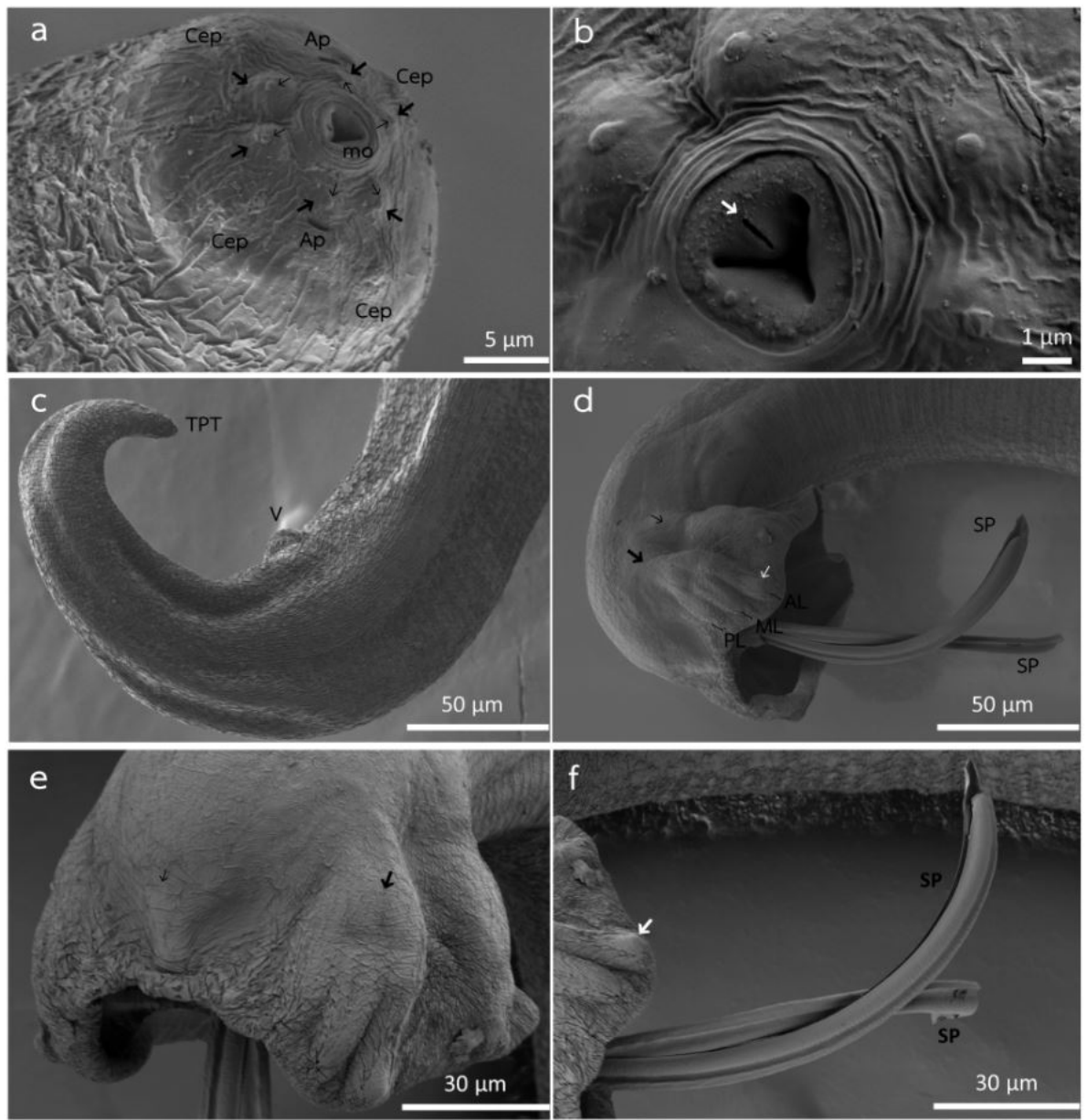

Figure 4. Scanning electron microscopy photomicrographs of $A$. minasensis. Anterior extremity, showing triangular opening of the oral opening (mo); six labial papillae (black thick arrows) with six small protuberances (black fine arrows); amphidial pores (Ap) and four cephalic papillae (CeP) (a). Magnification of the anterior extremity, showing a structure with a slit on the dorsal side of the mouth, which was named "tooth-like" (white thick arrow) (b). Posterior extremity of the female in lateral view, showing the vulva (V) and the long and sharp tail (TPT) (c). Posterior extremity of the male with the copulatory bursa in lateral view, showing: on the dorsal side, the lateral trunk (black thick arrow) with the anterolateral rays (AL) with one papilla (white arrow), mediolateral rays (ML) and posterolateral rays (PL); ventral trunk (black think arrow) and spicules (SP) (d). Copulatory bursa in dorsal view, showing the reduced dorsal ray (thin arrow) and lateral trunk (black thick arrow) (e). Spicules trough-shaped and, showing striated topography (SP); papilla in the anterolateral ray (white arrow) (f).

Female. [Based on one allotype and 10 paratypes; Figures $2 \mathrm{~b}$ and 3b] Body $18.4 \mathrm{~mm}$ [16.25-20.83 (19.13 \pm 1.5$)]$ long and $0.22 \mathrm{~mm}[0.23-0.26(0.24 \pm 0.01)]$ wide. Esophagus $0.23 \mathrm{~mm}[0.22-0.25(0.24 \pm 0.01)]$ long and $0.03 \mathrm{~mm}[0.03-0.05(0.04 \pm 0.005)]$ wide at its base. Nerve ring and excretory pore $0.069 \mathrm{~mm}[0.066-0.073(0.07 \pm 0.003)]$ and $0.035 \mathrm{~mm}$ [0.38-0.44 $(0.41 \pm 0.02)]$ from anterior end, respectively. Monodelphic. Vulva aperture 0.36 
$\mathrm{mm}$ [0.31-0.37 $(0.34 \pm 0.020)]$ from posterior extremity, with protuberant lips. In live specimens, the uterine tubules can be seen to spiral around the blood-filled intestine, and this can be seen through the transparent cuticle. Anus $0.09 \mathrm{~mm}$ [0.08-0.09 $0.09 \pm$ 0.005)] from posterior end. Long tail ventrally curved with a tapered tip. SEM results showed that the vulvar opening was near to the posterior end of the body and the long and sharp tail (Figure 4c).

First stage larvae. $[n=7]$ Using the Baermann apparatus, L1 were recovered from the rectum of all the necropsied animals. Body $290 \mu \mathrm{m} \pm 0.01(260 \mu \mathrm{m}-290 \mu \mathrm{m})$ long and $10 \mu \mathrm{m} \pm 0.004(10 \mu \mathrm{m}-20 \mu \mathrm{m})$ wide. Esophagus is slender, measuring $130 \mu \mathrm{m} \pm 0.007$ $(110 \mu \mathrm{m}-130 \mu \mathrm{m})$ in length. The intestine is a thin tube. Anus is located $24 \mu \mathrm{m} \pm 0.002$ $(23 \mu \mathrm{m}-27 \mu \mathrm{m})$ from the distal end. The tail ends at an unguiform appendix on dorsal surface.

\section{Taxonomic}

The copulatory bursa and spicules of $A$. minasensis n. sp. differed from those of the Angiostrongylus species previously described. It has a longer externodorsal ray than its dorsal ray, thus differing from A. raillieti, A. felineus, A. sandarsae, A. dujardini, A. lenzii, $A$. siamensis and $A$. morerai, which have externodorsal rays that are smaller than or equivalent in length to the dorsal ray (Travassos, 1927; Alicata, 1968; Dróźdź \& Doby, 1970; Ohbayashi et al., 1979; Robles et al., 2008; Souza et al., 2009; Vieira et al., 2013).

Although eight species of Angiostrongylus also have longer externodorsal rays than their dorsal rays, they can be differentiated from $A$. minasensis n. sp. by the lateral rays, the ventral rays and the length of the spicules. $A$. minasensis $\mathrm{n}$. sp. has ventral trunk rays that are more robust, and its spicules are shorter than those of $A$. vasorum and A. gubernaculatus (Baillet, 1957; Dougherty, 1946; Duarte et al., 2007). Angiostrongylus minasensis $\mathrm{n}$. sp. differs from $A$. chabaudi and $A$. costaricensis because its externodorsal ray is separated from the lateral trunk and its spicules are shorter (Biocca, 1957; Morera \& Céspedes, 1970). The new species differ from $A$. taterona because the anterolateral ray bifurcates close to the base of the lateral trunk, while the mediolateral and posterolateral rays bifurcate in the distal third of the trunk. Moreover, the spicules are shorter (spicules of $A$. minasensis $\mathrm{n}$. sp. measured $240-270 \mu \mathrm{m}$ versus $500-620 \mu \mathrm{m}$ in A. taterone) (Baylis, 1928).

Angiostrongylus minasensis n. sp. differs from A. cantonensis and A. malaysiensis (Chen, 1935; Bhaibulaya \& Cross, 1971) because it possesses a lateral trunk with almost equivalent length of rays. It also differs from $A$. mackerrasae and $A$. schmidti (Bhaibulaya, 1968; Kinsella, 1971), since its lateral trunk rays bifurcate at various levels and its spicules are smaller (spicules of $A$. minasensis n. sp. measured 240-270 $\mu \mathrm{m}$, versus $420 \mu \mathrm{m}$ in A. schmidti). Angiostrongylus minasensis $\mathrm{n}$. sp. differs from A. ryjikovi (Jushkov, 1971) through its posterolateral ray that is similar in length to the mediolateral ray. It also differs from $A$. daskalovi (Yanchev \& Genov, 1988) with respect to its spicules (spicules of A. minasensis n. sp. measured 240-270 $\mu \mathrm{m}$, versus 336-409 $\mu \mathrm{m}$ in A. daskalovi).

The species that was found in $N$. nasua differs morphologically from $A$. costaricensis. The rays of the copulatory bursa of $A$. minasensis $\mathrm{n}$. sp. lack dilations in the distal extremity and have a slender externodorsal ray. The externodorsal ray of $A$. costaricensis is approximately the same thickness as the rays of the lateral trunk, has the same dilation in the distal extremity and presents longer spicules. The posterior extremity of the female of $A$. minasensis n. sp. is longer and sharper than that of $A$. costaricensis and $A$. vasorum, which is roughly conical and slightly curved in both of these species (Morera \& Céspedes, 1970; Duarte et al., 2007). The tails of females of $A$. siamensis and $A$. minasensis are of the same length and sharpness, but the copulatory bursa of males of $A$. siamensis is smaller and presents shorter rays (Ohbayashi et al., 1979). 
Finally, A. minasensis $\mathrm{n}$. $\mathrm{sp}$. is morphometrically different from all other species found at the same site of infection (mesenteric arteries) and different from all other species found in the order Carnivora, as described in Table 2.

Table 2. Measurements (in millimetres) from A. minasensis n. sp. (10 males and 10 females) in comparison with five other species of Angiostrongylus.

\begin{tabular}{|c|c|c|c|c|c|c|}
\hline & A. minasensis & A. costaricensis & A. siamensis & $\begin{array}{c}\text { A. } \\
\text { gubernaculatus }\end{array}$ & A. vasorum & A. chabaudi \\
\hline Reference & & $\begin{array}{c}\text { Morera \& } \\
\text { Céspedes (1970) }\end{array}$ & $\begin{array}{c}\text { Ohbayashi et al. } \\
\text { (1979) }\end{array}$ & $\begin{array}{c}\text { Dougherty } \\
\text { (1946) }\end{array}$ & $\begin{array}{c}\text { Guilhon \& Cens } \\
\text { (1973) }\end{array}$ & Biocca (1957) \\
\hline Host & Nasua nasua & Man & $\begin{array}{l}\text { Rattus sabanus, } \\
\text { R. berdmorei }\end{array}$ & $\begin{array}{c}\text { Taxidea taxus } \\
\text { neglecta Mearns }\end{array}$ & $\begin{array}{l}\text { Canis lupus } \\
\text { familiaris }\end{array}$ & Felis silvestris \\
\hline Locality & Brazil & Costa Rica & Thailand & California & France & Central Italy \\
\hline \multicolumn{7}{|l|}{ MALE } \\
\hline Length & $12.12-14.1$ & $15.0-17.9$ & 10 & $18-19.5$ & $14-15.5$ & $14.6-16.3$ \\
\hline Width & $0.19-0.22$ & - & - & 0.3 & - & $0.185-0.225$ \\
\hline Oesophagus & $0.2-0.25$ & $0.16-0.18$ & 0.23 & $0.3-0.34$ & $0.22-0.28$ & $0.3-0.345$ \\
\hline Nerve ring & $0.064-0.075$ & - & - & - & $0.08-0.092$ & $0.185-0.23$ \\
\hline Excretory pore & $0.3-0.37$ & - & 0.32 & - & $0.31-0.35$ & $0.335-0.405$ \\
\hline Spicule & $0.24-0.27$ & $0.267-0.297$ & 0.339 & $0.52-0.56$ & $0.4-0.48$ & $0.510-0.555$ \\
\hline Gubernaculum & $0.034-0.045$ & Present & Present & $0.045-0.05$ & $0-04-0.055$ & Absent \\
\hline \multicolumn{7}{|l|}{ FEMALE } \\
\hline Length & $16.25-20.83$ & 26.9 & $11-13$ & $22-24$ & $15-20.5$ & $19.8-24.1$ \\
\hline Width & $0.23-0.26$ & - & - & 0.35 & - & $0.245-0.298$ \\
\hline Oesophagus & $0.22-0.26$ & $0.10-0.26$ & $0.23-0.27$ & $0.34-0.35$ & $0.24-0.28$ & $0.345-0.38$ \\
\hline Nerve ring & $0.066-0.073$ & - & - & - & $0.08-0.096$ & $0.21-0.24$ \\
\hline Excretory pore & $0.38-0.44$ & - & $0.32-0.36$ & - & $0.35-0.37$ & $0.395-0.47$ \\
\hline Vulva-tail & $0.31-0.37$ & 0.175 & $0.3-0.38$ & $\begin{array}{c}0.21-0.26 \text { (vulva- } \\
\text { anus) }\end{array}$ & $0.22-0.315$ & $0.17-0.21$ \\
\hline Anus-tail & $0.08-0.09$ & 0.053 & $0.07-0.1$ & $0.075-0.09$ & $0.061-0.1$ & $0.062-0.075$ \\
\hline
\end{tabular}

(-) represents lack of data.

\section{Phylogenetic analysis}

The aligned sequences resulted in a matrix comprising 18 taxa and 702 characteristics, of which 459 were constant and 190 were variable characteristics that were informative for parsimony. The phylogenies described here were based on the MT-CO1 gene and were inferred using two different optimality criteria ( $\mathrm{ML}$ and $\mathrm{BI})$, which resulted in similar topologies with little variation in nodes and support values (Figure 5). 


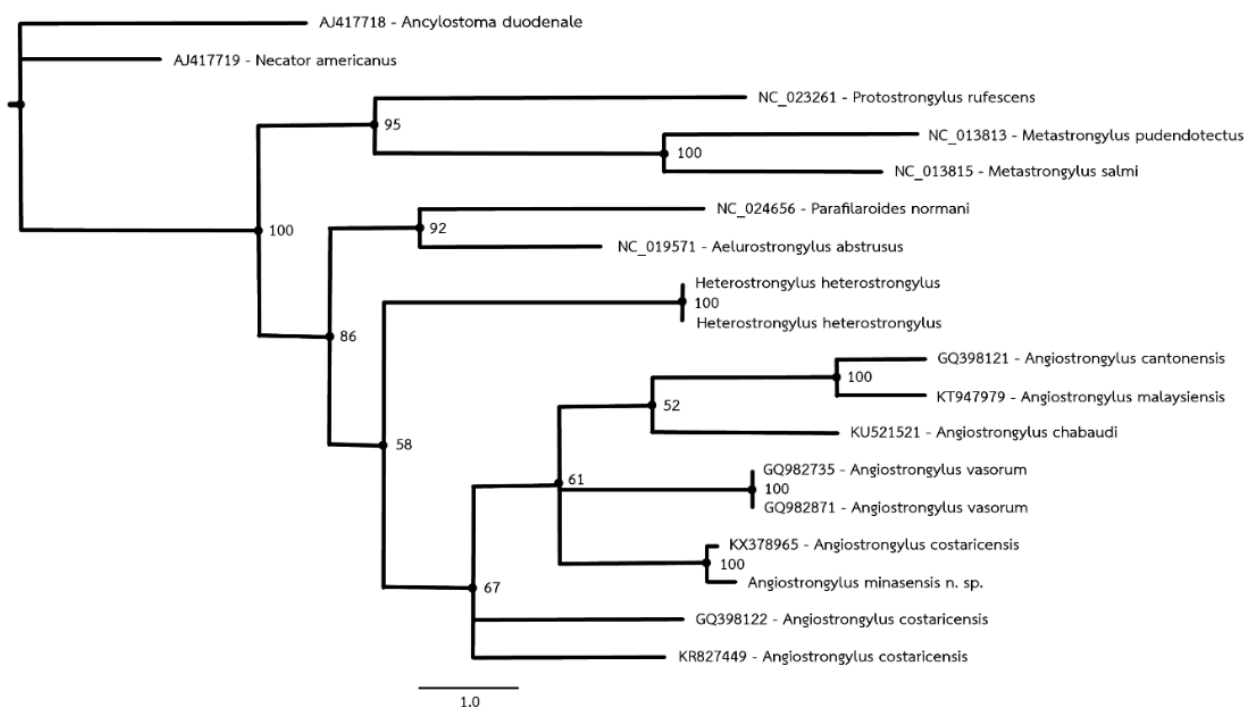

Figure 5. Bayesian phylogenetic reconstruction, based on the MT-CO1 gene. Values at the nodes are the Bayesian posterior probabilities. Scale bar represents branch lengths in substitutions per site.

The ML method resulted in a tree with InL score $=-3642.256$. The evolutionary models selected through BIC were as follows: $\mathrm{HKY}+\mathrm{G}$ with fixed substitution rates $(3,1,1,1,1,3)$; frequency of bases and gamma distribution optimized in the first codon position and independent $\mathrm{J} 1+\mathrm{G}$ with substitution rates; and frequency of bases and proportion of invariable sites optimized in the second and third codon positions.

The BI method resulted in values that were highly significant for all the parameters for the estimated size of the sample (ESS). The genera Angiostrongylus, Heterostrongylus, Aelurostrongylus and Parafilaroides formed a monophyletic group in both topologies with support ranging from low to moderate (LR-ELW $=76 \%$, ML-BP $<50 \%$, BPP $=86 \%$ ). The genus Angiostrongylus was monophyletic in the Bl topology with low support $(\mathrm{BPP}=67 \%)$.

Angiostrongylus minasensis $\mathrm{n}$. $\mathrm{sp}$. was a sister to the specimen isolated from Nasua narica (Santoro et al., 2016) with strong support in all topologies (LR-ELW = 93\%; ML-BP = 99\%; $\mathrm{BPP}=100 \%)$. The genetic lineage formed by Angiostrongylus in coatis was connected via basal polytomy to the lineage formed by $A$. vasorum and the lineage formed by A. cantonensis, A. malaysiensis and A. chabaudi, with low support in the $\mathrm{BI}$ topology $(\mathrm{BPP}=61 \%)$.

ML-pairwise genetic distances of the MT-CO1 gene between Angiostrongylus species ranged from $6.8 \%$ between $A$. cantonensis and $A$. malaysiensis to $27.3 \%$ between A. chabaudi and $A$. costaricensis. Distances between genera ranged from $16.1 \%$ between Necator and Ancylostoma to $41.4 \%$ between Ancylostoma and Angiostrongylus. Distances between Aelurostrongylus, Heterostrongylus and Angiostrongylus species sequences ranged from $20.8 \%$ to $31.1 \%$. The distance within Angiostrongylus taxa from coatis was $0.2 \%$, whereas the distance within $A$. costaricensis was $13.3 \%$. The distances between Angiostrongylus taxa from coatis and $A$. costaricensis taxa ranged from $16.2 \%$ to $18.5 \%$ (Table 3). 
Table 3. Pairwise ML genetic distances of the MT-CO1 gene between A. minasensis $\mathrm{n}$. sp (bold) and other strongylids.

\begin{tabular}{|c|c|c|c|c|c|c|c|c|c|c|c|c|c|c|c|c|}
\hline & 2 & 3 & 4 & 5 & 6 & 7 & 8 & 9 & 10 & 11 & 12 & 13 & 14 & 15 & 16 & 17 \\
\hline $\begin{array}{l}\text { 1. Ancylostoma } \\
\text { duodenale } \\
\text { (A)417718) }\end{array}$ & & & & & & & & & & & & & & & & \\
\hline $\begin{array}{l}\text { 2. Necator } \\
\text { americanus } \\
\text { (AJ417719) }\end{array}$ & & & & & & & & & & & & & & & & \\
\hline $\begin{array}{l}\text { 3. Protostrongylus } \\
\text { rufescens } \\
\text { (NC_023262) }\end{array}$ & 37.240 & & & & & & & & & & & & & & & \\
\hline $\begin{array}{l}\text { 4. Metastrongylus } \\
\text { pudendotectus } \\
\text { (NC013813) }\end{array}$ & 38.343 & 35.950 & & & & & & & & & & & & & & \\
\hline $\begin{array}{l}\text { 5. Metastrongylus } \\
\text { salmi } \\
\text { (NC013815) }\end{array}$ & 45.664 & 42.342 & 20.002 & & & & & & & & & & & & & \\
\hline $\begin{array}{l}\text { 6. Parafilaroides } \\
\text { normani } \\
\text { (NC024656) }\end{array}$ & 24.342 & 30.736 & 31.055 & 35.661 & & & & & & & & & & & & \\
\hline $\begin{array}{l}7 . \\
\text { Heterostrongylus } \\
\text { heterostrongylus } \\
\text { (llha Grande, RJ) }\end{array}$ & 27.033 & 34.833 & 32.439 & 35.547 & 25.143 & & & & & & & & & & & \\
\hline $\begin{array}{l}8 . \\
\text { Heterostrongylus } \\
\text { heterostrongylus } \\
\text { (PEPB/CFMA, RJ) }\end{array}$ & 26.825 & 34.858 & 32.315 & 35.627 & 24.855 & 0.007 & & & & & & & & & & \\
\hline $\begin{array}{l}9 . \\
\text { Aelurostrongylus } \\
\text { abstrusus } \\
\text { (NC019571) }\end{array}$ & 27.617 & 28.646 & 37.879 & 31.581 & 20.158 & 20.917 & 20.834 & & & & & & & & & \\
\hline $\begin{array}{l}10 . \\
\text { Angiostrongylus } \\
\text { cantonensis } \\
\text { (GQ398121) }\end{array}$ & 25.772 & 36.751 & 37.191 & 36.876 & 27.641 & 21.953 & 22.020 & 23.555 & & & & & & & & \\
\hline $\begin{array}{l}11 . \\
\text { Angiostrongylus } \\
\text { malaysiensis } \\
\text { (KT947979) }\end{array}$ & 31.707 & 35.441 & 39.113 & 38.985 & 30.821 & 24.849 & 24.834 & 26.821 & 6.851 & & & & & & & \\
\hline $\begin{array}{l}12 . \\
\text { Angiostrongylus } \\
\text { chabaudi } \\
\text { (KU521521) }\end{array}$ & 31.619 & 37.349 & 43.042 & 40.547 & 30.834 & 31.075 & 31.107 & 28.164 & 20.284 & 19.502 & & & & & & \\
\hline $\begin{array}{l}13 . \\
\text { Angiostrongylus } \\
\text { vasorum } \\
\text { (GQ982735) }\end{array}$ & 30.756 & 37.879 & 37.246 & 38.593 & 23.388 & 28.032 & 27.959 & 24.266 & 21.889 & 23.614 & 14.273 & & & & & \\
\hline
\end{tabular}


Table 3. Continued...

\begin{tabular}{|c|c|c|c|c|c|c|c|c|c|c|c|c|c|c|c|c|}
\hline & 2 & 3 & 4 & 5 & 6 & 7 & 8 & 9 & 10 & 11 & 12 & 13 & 14 & 15 & 16 & 17 \\
\hline $\begin{array}{l}14 . \\
\text { Angiostrongylus } \\
\text { vasorum } \\
\text { (GQ982871) }\end{array}$ & 30.804 & 37.872 & 37.293 & 38.587 & 23.386 & 28.078 & 28.006 & 24.315 & 21.886 & 23.610 & 14.326 & 0.003 & & & & \\
\hline $\begin{array}{l}15 . \\
\text { Angiostrongylus } \\
\text { costaricensis } \\
\text { (GQ398122) }\end{array}$ & 30.033 & 37.828 & 36.428 & 30.768 & 26.478 & 21.172 & 21.296 & 20.626 & 20.013 & 21.170 & 21.327 & 18.523 & 18.520 & & & \\
\hline $\begin{array}{l}16 . \\
\text { Angiostrongylus } \\
\text { costaricensis } \\
\text { (KR827449) }\end{array}$ & 29.261 & 30.774 & 33.170 & 27.778 & 26.751 & 23.981 & 24.094 & 20.862 & 19.454 & 19.216 & 27.288 & 21.502 & 21.499 & 13.280 & & \\
\hline $\begin{array}{l}17 . \\
\text { Angiostrongylus } \\
\text { costaricensis } \\
\text { (KX378965) }\end{array}$ & 30.746 & 38.294 & 37.080 & 36.371 & 28.946 & 23.149 & 23.103 & 25.270 & 17.715 & 17.172 & 16.790 & 16.262 & 16.258 & 16.172 & 17.539 & \\
\hline $\begin{array}{l}18 . \\
\text { Angiostrongylus } \\
\text { minasensis n. } \\
\text { sp. }\end{array}$ & 30.828 & 37.776 & 35.207 & 35.380 & 28.988 & 23.065 & 22.832 & 25.307 & 19.866 & 18.284 & 17.989 & 17.007 & 17.003 & 18.439 & 17.466 & 0.233 \\
\hline
\end{tabular}

\section{Discussion}

The finding of helminths harbored in the mesenteric arteries of coatis from the Mangabeiras Park in Belo Horizonte (state of Minas Gerais, Brazil) initially suggested the possibility of infection by $A$. costaricensis, because this species has been reported infecting rodents and N. narica coatis in the Americas (Morera, 1973; Monge et al., 1978; Santoro et al., 2016). An alternative explanation was that the animals were infected by A. siamensis, which has been described infecting rodents in Thailand (Ohbayashi et al., 1979), since the latter species was also found infecting the mesenteric arteries of the caecum.

Given that Angiostrongylus spp. present low specificity to their vertebrate hosts, we examined the possibility that the species described here was A. vasorum, because this species has been described parasitizing domestic and wild canids in the state of Minas Gerais (Lima et al., 1985; Lima et al., 1994). However, morphological evaluation of the posterior extremity of the specimens of the present study that were found parasitizing coatis, in comparison with species found at the same infection sites and all the species found parasitizing carnivores, allowed us to conclude that the Angiostrongylus sp. described here could not be identified as any of the above mentioned species and is, therefore, a new species.

The ML-pairwise genetic distances of the MT-CO1 gene showed that $A$. minasensis n. $\mathrm{sp}$. is significantly distant from the $A$. costaricensis taxa isolated from rodents in Brazil and Costa Rica. On the other hand, the genetic distance between $A$. minasensis $\mathrm{n}$. sp. recovered from Nasua nasua in Brazil and A. costaricensis isolated from N. narica from Costa Rica is small and is only larger than the distance between the European sequences of $A$. vasorum. Similarly, the distances between the A. costaricensis taxa from N. narica and rodents, both from Costa Rica, are also significantly large. The phylogenetic analyses presented here suggest that $A$. minasensis $\mathrm{n}$. sp. corresponds to a new taxon. 
Interestingly, the new species is closely related to the $A$. costaricensis taxon occurring in N. narica in Costa Rica.

Angiostrongylus costaricensis may also have low host specificity, since it parasitizes primates and the marsupial Didelphis virginiana, and Procyon lotor in Miami (Florida, USA) (Miller et al., 2006). However, L1 larvae isolated from faeces was not reported in these cases (Miller et al., 2006). In the present study, the occurrence of L1 in all the samples of feces from all the coatis that presented the adult parasite suggests that $N$. nasua is the natural host of $A$. minasensis $\mathrm{n}$. sp. In this area, coatis occur at high population densities due to the absence of natural predators and the high abundance of food offered and discarded by humans (Porfírio et al., 2006). The Mangabeiras Park is located on the border between the metropolitan area of Belo Horizonte, which is subjected to anthropic pressure, and a conservation area (Serra do Curral), which could facilitate animal dispersion (Porfírio et al., 2006).

\section{Conclusion}

Angiostrongylus minasensis $\mathrm{n}$. $\mathrm{sp}$. is a new species of Angiostrongylus found in the mesenteric arteries of Nasua nasua in Brazil.

\section{Acknowledgements}

The authors would like to thank the Oswaldo Cruz Institute for its help in DNA sequencing; IBAMA's wild animal screening center; and the Projeto Quatis and parks foundation of Prefeitura of Belo Horizonte, Minas Gerais. We also would like to thank Marco Anacleto (Scientific Illustration Laboratory, Instituto de Ciências Biológicas, Federal University of Minas Gerais, Brazil), and Andrea Kauffmann for the translation. We thank the Research Support Foundation of the State of Minas Gerais (Fundação de Amparo à Pesquisa do Estado de Minas Gerais, FAPEMIG) for its financial support (WSL, grant number 18898), and the National Council for Scientific and Technological Development (Conselho Nacional de Desenvolvimento Científico e Tecnológico, CNPq) for its financial support (WSL, grant number 480469/2012-1).

\section{References}

Alicata JE. Angiostrongylus sandarsae sp. n. (Nematoda: Metastrongyloidea), a lungworm of rodents in Mozambique, East Africa. J Parasito/ 1968; 54(5): 896-899. http://dx.doi.org/10.2307/3277116.

Alves-Costa CP, Fonseca GAB, Christófaro C. Variation in the diet of the brown-nosed coati (Nasua nasua) in southeastern Brazil. J Mammal 2004; 85(3): 478-482. http://dx.doi.org/10.1644/15451542(2004)085<0478:VITDOT>2.0.CO;2.

Anderson RC, Chabaud AG, Willmott S. Keys to the nematode parasites of vertebrates: archival volume. London: CABI International; 2009. http://dx.doi.org/10.1079/9781845935726.0000.

Baillet CC. Strongyle des vaisseaux et du Coeur du chien. Strongylus vasorum (Nobis). N Dict Paract Med Vet 1957; 8: 587-588.

Barçante JM, Barçante TA, Dias SR, Vieira LQ, Lima WS, Negrão-Corrêa D. A method to obtain axenic Angiostrongylus vasorum first-stage larvae from dog feces. Parasitol Res 2003; 89(2): 89-93. http://dx.doi.org/10.1007/s00436-002-0719-z. PMid:12489005.

Baylis HA. On a collection of nematodes from Nigerian mammals (chiefly rodents). Parasitology 1928; 20(3): 280-304. http://dx.doi.org/10.1017/S0031182000011707.

Bhaibulaya M, Cross JH. Angiostrongylus malaysiensis (Nematoda: Metastrongylidae), a new species of rat lung-worm from Malaysia. Southeast Asian J Trop Med Public Health 1971; 2(4): 527-533. PMid:5144154.

Bhaibulaya M. A new species of Angiostrongylus in an Australian rat, Ratus fuscipes. Parasitology 1968; 58(4): 789-799. http://dx.doi.org/10.1017/S0031182000069572. 
Biocca E. Angiostrongylus chabaudi n. sp. parassita del cuore e dei vasi polmonari del gatto selvatico (Felis silvestris). Lincei Rend Sc Fis Mat Nat. 1957; 22(4): 526-532.

Chen HT. Un nouveau nématode pulmonaire, Pulmonema cantonensis, n. g., n. sp. Ann Parasitol Hum Comp 1935; 13(4): 312-317. http://dx.doi.org/10.1051/parasite/1935134312.

Costa SF No, Oliveira Simões R, Mota ÉM, Val Vilela R, Lopes Torres EJ, Santos Barbosa H, et al. Lungworm Heterostrongylus heterostrongylus Travassos, 1925 from the black-eared opossum in South America: Morphologic, histopathological and phylogenetic aspects. Vet Parasitol 2016; 228: 144-152. http://dx.doi.org/10.1016/j.vetpar.2016.08.018. PMid:27692317.

Crespo JA. Ecologia de la comunidad de mamíferos del parque Nacional Iguazú, Misiones. Rev Macn Ecología. 1982; 3(2): 145-162.

Decker DM. Systematics of the coatis, genus Nasua (Mammalia, Procyonidae). Proc Biol Soc Wash 1991; 104(2): 370-386.

Dougherty EC. The genus Aelurostrongylus Cameron, 1927 (Nematoda: Metastrongylidae) and its relatives; with descriptions of Parafilaroides gen. nov., and Angiostrongylus gubernaculatus sp. nov. Proc Helminthol Soc Wash 1946; 13: 16-26. PMid:21026155.

Dróźdź J, Doby JM. Angiostrongylus dujardini sp. n. (Nematoda: Metastrongyloidea) parasite de rongeurs (Apodemus sylvaticus et Clethrionomys glareolus). Bull Soc Zoolr 1970; 95(4): 659-668.

Duarte FH, Vieira FM, Louzada GL, Bessa ECA, Souzalima S. Occurrence Angiostrongylus vasorum (Baillet, 1866) (Nematoda, Angiostrongylidae) in Cerdocyon thous Linnaeus, 1766 (Carnivora, Canidae) in Minas Gerais State Brazil. Arq Bras Med Vet Zootec 2007; 59(4): 1086-1088. http://dx.doi.org/10.1590/S0102-09352007000400042.

Gherman CM, Ionică AM, D'Amico G, Otranto D, Mihalca AD. Angiostrongylus chabaudi (Biocca, 1957) in wildcat (Felis silvestris silvestris, S) from Romania. Parasitol Res 2016; 115(6): 2511-2517. http://dx.doi.org/10.1007/s00436-016-5032-3. PMid:27106235.

Gompper ME, Decker DM. Nasua nasua. Mammal Sp 1998; 580(580): 1-9. http://dx.doi.org/10.2307/3504444.

Guilhon J, Cens B. Angiostrongylus vasorum (Baillet, 1866): étude biologique et morphologique. Ann Parasitol Hum Comp 1973; 48(4): 567-596. http://dx.doi.org/10.1051/parasite/1973484567. PMid:4791829.

$\mathrm{Hu}$ M, Chilton NB, Gasser RB. The mitochondrial genomes of the human hookworms, Ancylostoma duodenale and Necator americanus (Nematoda: secernentea). Int J Parasitol 2002; 32(2): 145-158. http://dx.doi.org/10.1016/S0020-7519(01)00316-2. PMid:11812491.

Jabbar A, Jex AR, Mohandas N, Hall RS, Littlewood DTJ, Gasser RB. The mitochondrial genome of Aelurostrongylus abstrusus diagnostic, epidemiological and systematic implications. Gene 2013a; 516(2): 294-300. http://dx.doi.org/10.1016/j.gene.2012.10.072. PMid:23142387.

Jabbar A, Mohandas N, Jex AR, Gasser RB. The mitochondrial genome of Protostrongylus rufescensimplications for population and systematic studies. Parasit Vectors 2013b; 6(1): 263. http://dx.doi.org/10.1186/1756-3305-6-263. PMid:24025317.

Jabbar A, Mohandas N, Gasser RB. Characterisation of the mitochondrial genome of Parafilaroides normani (lungworm) of Arctocephalus pusillus doriferus (Australian fur seal). Parasitol Res 2014; 113(8): 3049-3055. http://dx.doi.org/10.1007/s00436-014-3968-8. PMid:24924434.

Jefferies R, Shaw SE, Viney ME, Morgan ER. Angiostrongylus vasorum from South America and Europe represent distinct lineages. Parasitology 2009; 136(1): 107-115. http://dx.doi.org/10.1017/S0031182008005258. PMid:19126274.

Jefferies R, Shaw SE, Willesen J, Viney ME, Morgan ER. Elucidating the spread of the emerging canid nematode Angiostrongylus vasorum between Palaearctic and Nearctic ecozones. Infect Genet Evol 2010; 10(4): 561-568. http://dx.doi.org/10.1016/j.meegid.2010.01.013. PMid:20139034.

Jex AR, Hall RS, Littlewood DTJ, Gasser RB. An integrated pipeline for next-generation sequencing and annotation of mitochondrial genomes. Nucleic Acids Res 2010; 38(2): 522-533. http://dx.doi.org/10.1093/nar/gkp883. PMid:19892826.

Jobb G. Treefinder version of march 2011 - software distributed by the author [online]. 2011 [cited 2017 jun 17]. Available from: http://www.treefinder.de 
Jukes TH, Cantor CR. Evolution of protein molecules. In: Munro HN, editors. Mammalian protein metabolism. New York: Academic Press; 1969; p. 21-132. http://dx.doi.org/10.1016/B978-1-48323211-9.50009-7.

Jushkov VF. Angiocaulus ryjikovi sp. n. (Nematoda: Strongylata), a parasite of the northern red-backed vole (Clethrionomys rutilus Pallas) from northern Ural. Parazitologiya 1971; 4: 344-346.

Kearse M, Moir R, Wilson A, Stones-Havas S, Cheung M, Sturrock S, et al. Geneious Basic: an integrated and extendable desktop software platform for the organization and analysis of sequence data. Bioinformatics 2012; 28(12): 1647-1649. http://dx.doi.org/10.1093/bioinformatics/bts199. PMid:22543367.

Kinsella JM. Angiostrongylus schmidti sp. n. (Nematoda: Metastrongyloidea) from the rice rat, Oryzomys palustris, in Florida, with a key to the species of Angiostrongylus Kamenky, 1905.J Parasitol 1971; 57(3): 494-497. http://dx.doi.org/10.2307/3277901. PMid:5104560.

Lima WS, Costa HMA, Guimarães MP, Leite AC. Angiostrongylus vasorum (Baillet, 1866) Nematoda: Protostrongylidae, em cães de Minas Gerais, Brasil. Mem Inst Oswaldo Cruz 1985; 80(2): 233-235. http://dx.doi.org/10.1590/S0074-02761985000200015. PMid:3836330.

Lima WS, Guimarães MP, Lemos IS. Occurrence of Angiostrongylus vasorum in the lungs of the Brazilian fox Dusicyon vetulus. J Helminthol 1994; 68(1): 87. http://dx.doi.org/10.1017/S0022149X00013547. PMid:8006392.

Lopes EJT, Souza W, Miranda K. Comparative analysis of Trichuris muris surface using conventional, low vacuum, environmental and field emission scanning electron microscopy. Vet Parasitol 2013; 196(3-4): 409-416. http://dx.doi.org/10.1016/j.vetpar.2013.02.026. PMid:23537947.

Lv S, Zhang Y, Zhang L, Liu Q, Liu HX, Hu L, et al. The complete mitochondrial genome of the rodent intra-arterial nematodes Angiostrongylus cantonensis and Angiostrongylus costaricensis. Parasitol Res 2012; 111(1): 115-123. http://dx.doi.org/10.1007/s00436-011-2807-4. PMid:22246368.

Maddison WP, Maddison DR. Mesquite: a modular system for evolutionary analysis - Version 3.04 [online]. 2015 [cited 2017 jun 17]. Available from: http://mesquiteproject.org

Maldonado A, Simões R, Thiengo SC. Angiostrongyliasis in the Americas. In: Lorenzo-Morales J, editors. Zoonosis. London: IntechOpen. 2012. p. 303-320.

Miller CL, Kinsella JM, Garner MM, Evans S, Gullett PA, Schmidt RE. Endemic infections of Parastrongylus (=Angiostrongylus) costaricensis in two species of nonhuman primates, raccoons, and an opossum from Miami, Florida. J Parasitol 2006; 92(2): 406-408. http://dx.doi.org/10.1645/GE-653R.1. PMid:16729706.

Miller MA, Pfeiffer W, Schwartz T. Creating the CIPRES Science Gateway for inference of large phylogenetic trees. New Orleans: IEEE; 2010. http://dx.doi.org/10.1109/GCE.2010.5676129.

Monge E, Arroyo R, Solano E. A new definitive natural host of Angiostrongylus costaricensis (Morera and Céspedes 1971). J Parasitol 1978; 64(1): 34. http://dx.doi.org/10.2307/3279604. PMid:627972.

Morera P, Céspedes R. Angiostrongylus costaricensis n. sp. (Nematoda: Metastrongyloidea), a new lungworm occurring in man in Costa Rica. Rev Biol Trop 1970; 18(1): 173-185. PMid:5527668.

Morera P. Life history and redescription of Angiostrongylus costaricensis Morera and Céspedes, 1971. Am J Trop Med Hyg 1973; 22(5): 613-621. http://dx.doi.org/10.4269/ajtmh.1973.22.613. PMid:4729741.

Ohbayashi M, Kamiya M, Bhaibulaya M. Studies on the parasite fauna of Thailand I. Two new metastrongylid nematodes, Angiostrongylus siamensis sp. $\mathrm{n}$. and Thaistrongylus harinasutai gen. et sp. n. (Metastrongyloidea; Angiostrongylidae) from wild rats. Jpn J Vet Res 1979; 27(1-2): 5-10. PMid:529658.

Porfírio THC, Barreto FCC, Souza AL, Gonçalves W. Formas de interação de três bairros periféricos com o Parque Municipal das Mangabeiras, Belo Horizonte, Minas Gerais. Rev Arvore 2006; 30(6): 1033-1038. http://dx.doi.org/10.1590/S0100-67622006000600019.

Prosser SW, Velarde-Aguilar MG, León-Règagnon V, Hebert PD. Advancing nematode barcoding: a primer cocktail for the cytochrome c oxidase subunit I gene from vertebrate parasitic nematodes. Mol Ecol Resour 2013; 13(6): 1108-1115. http://dx.doi.org/10.1111/1755-0998.12082. PMid:23433320. 
Rambaut A, Suchard MA, Xie D, Drummond AJ. Tracer v1.6. 2014 [cited 2017 jun 17]. Available from http://beast.bio.ed.ac.uk/Tracer

Robles MR, Navone GT, Kinsella JM. A new Angiostrongylid (Nematoda) species from the pulmonary arteries of Akodon Azarae (Rodentia: Cricetidae) in Argentina. J Parasitol 2008; 94(2): 515-519. http://dx.doi.org/10.1645/GE-1340.1. PMid:18564753.

Ronquist F, Teslenko M, Van Der Mark P, Ayres DL, Darling A, Hohna S, et al. MrBayes 3.2: efficient bayesian phylogenetic inference and model choice across a large model space. Syst Biol 2012; 61(3): 539-542. http://dx.doi.org/10.1093/sysbio/sys029. PMid:22357727.

Santoro M, Alfaro-Alarcón A, Veneziano V, Cerrone A, Latrofa MS, Otranto D, et al. The white-nosed coati (Nasua narica) is a naturally susceptible definitive host for the zoonotic nematode Angiostrongylus costaricensis in Costa Rica. Vet Parasitol 2016; 228: 93-95. http://dx.doi.org/10.1016/j.vetpar.2016.08.017. PMid:27692339.

Schwarz G. Estimating the dimension of a model. Ann Stat 1978; 6(2): 461-464. http://dx.doi.org/10.1214/aos/1176344136.

Souza JG, Simões RO, Thiengo SA, Lima WS, Mota EM, Rodrigues-Silva R, et al. A new metastrongilid species (Nematoda: Metastrongylidae): a lungworm from Akodon montensis (Rodentia: Sigmodontinae) in Brazil. J Parasito/ 2009; 95(6): 1507-1511. http://dx.doi.org/10.1645/GE-2013.1. PMid:19566346.

Spratt DM. Species of Angiostrongylus (Nematoda: Metastrongyloidea) in wildlife: A review. Int J Parasitol Parasites Wildl 2015; 4(2): 178-189. http://dx.doi.org/10.1016/j.ijppaw.2015.02.006. PMid:25853051.

Travassos L. Nematódeos novos. Bol Biol 1927; 6: 52-61.

Vieira FM, Muniz-Pereira LC, Lima SS, Moraes AH No, Guimarães EV, Luque JL. A new metastrongyloidean species (Nematoda) parasitizing pulmonary arteries of Puma (Herpailurus) yagouaroundi (É. Geoffroy, 1803) (Carnivora: Felidae) from Brazil. J Parasitol 2013; 99(2): 327-331. http://dx.doi.org/10.1645/GE-3171.1. PMid:23016945.

Xia X, Xie Z, Salemi M, Chen L, Wang Y. An index of substitution saturation and its application. Mol Phylogenet Evol 2003; 26(1): 1-7. http://dx.doi.org/10.1016/S1055-7903(02)00326-3. PMid:12470932.

Xia X. Information-theoretic indices and an approximate significance test for testing the molecular clock hypothesis with genetic distances. Mol Phylogenet Evol 2009; 52(3): 665-676. http://dx.doi.org/10.1016/j.ympev.2009.04.017. PMid:19416757.

Xia X. DAMBE5: a comprehensive software package for data analysis in molecular biology and evolution. Mol Biol Evol 2013; 30(7): 1720-1728. http://dx.doi.org/10.1093/molbev/mst064. PMid:23564938.

Yanchev J, Genov T. Angiostrongylus daskalovi sp. n. (Nematoda: Filaroididae) from Mustelidae in Bulgaria. Helminthologia 1988; 25: 81-88.

Yong HS, Song SL, Eamsobhana P, Goh SY, Lim PE, Chow WL, et al. Mitochondrial genome supports sibling species of Angiostrongylus costaricensis (Nematoda: angiostrongylidae). PLoS One 2015; 10(7): e0134581. http://dx.doi.org/10.1371/journal.pone.0134581. PMid:26230642.

Yong HS, Song SL, Eamsobhana P, Lim PE. Complete mitochondrial genome of Angiostrongylus malaysiensis lungworm and molecular phylogeny of Metastrongyloid nematodes. Acta Trop 2016; 161: 33-40. http://dx.doi.org/10.1016/j.actatropica.2016.05.002. PMid:27207134. 